NBER WORKING PAPER SERIES

\title{
IS THE INVISIBLE HAND DISCERNING OR INDISCRIMINATE? \\ INVESTMENT AND STOCK PRICES IN \\ THE AFTERMATH OF CAPITAL ACCOUNT LIBERALIZATIONS
}

\author{
Anusha Chari \\ Peter Blair Henry \\ Working Paper 10318 \\ http://www.nber.org/papers/w10318 \\ NATIONAL BUREAU OF ECONOMIC RESEARCH \\ 1050 Massachusetts Avenue \\ Cambridge, MA 02138 \\ February 2004
}

Henry gratefully acknowledges the financial support of an NSF CAREER award, the Stanford Institute of Economic Policy Research (SIEPR), and the Stanford Center for International Development (SCID). We thank Jack Glen for providing us with data. For helpful comments we thank Rui Albuquerque, Steve Buser, Menzie Chinn, Laura Kodres, Richard Roll, Paul Romer, Jeffrey Wurgler, and seminar participants at the AEA Annual Meetings, Claremont, LACEA-Madrid, Maryland, Michigan, NBER, Stanford, Wharton, The IMF Annual Research Conference, UCLA, WFA, and the World Bank. Any remaining errors are our own. The views expressed herein are those of the authors and not necessarily those of the National Bureau of Economic Research.

(O2004 by Anusha Chari and Peter Blair Henry. All rights reserved. Short sections of text, not to exceed two paragraphs, may be quoted without explicit permission provided that full credit, including $\odot$ notice, is given to the source. 
Is the Invisible Hand Discerning or Indiscriminate?

Investment and Stock Prices in The Aftermath of Capital Account Liberalizations

Anusha Chari and Peter Blair Henry

NBER Working Paper No. 10318

February 2004

JEL No. F3, F4

\begin{abstract}
We confront the two opposing views of capital account liberalization in developing countries with a new firm-level dataset on investment, stock prices, and sales. In the three-year period following liberalizations, the growth rate of the typical firm's capital stock exceeds its pre-liberalization mean by an average of 5.4 percentage points. The return to capital rises in the post-liberalization period, suggesting that the investment boom does not constitute a wasteful binge. In the cross section, changes in investment are significantly correlated with the signals about fundamentals embedded in the stock price changes that occur upon liberalization. Panel data estimations show that a 1percentage point increase in a firm's expected future cash flow predicts a 4.1-percentage point increase in its investment; the country-specific shock to the cost of capital predicts a 2.3-percentage point increase in investment; firm-specific changes in risk premia do not affect investment.

Anusha Chari

University of Michigan Business School

701 Tappan Street

Ann Arbor, MI 48109-1234

achari@bus.umich.edu

Peter Blair

Stanford University

Graduate School of Business

Stanford, CA 94305-5015

and NBER

pbhenry@stanford.edu
\end{abstract}




\section{Introduction}

Broadly speaking, there are two views of capital account liberalization and the invisible hand. The first view sees the invisible hand as discerning. Removing restrictions on international capital movements permits financial resources to flow from capital-abundant developed countries, where expected returns are low, to capital-scarce developing countries, where expected returns are high. The flow of resources into the developing countries reduces their cost of capital, increases investment, and raises output (Fischer, 2003; Obstfeld, 1998; Rogoff, 1999; Summers, 2000).

The second view sees the first as unsubstantiated and regards the invisible hand as indiscriminate. Indiscriminate hand proponents argue that liberalization does not produce a more efficient international allocation of capital. Instead, liberalizations generate speculative capital flows that are divorced from the fundamentals and have no discernible positive effects on investment, output, or any other real variable with nontrivial welfare implications (Bhagwhati, 1998; Rodrik, 1998; Stiglitz 1999, 2002).

While opinions about liberalization are abundant, facts are scarce (Fischer, 1998). This paper increases the ratio of facts to opinions by confronting the two views of liberalization with a new data set on investment, stock prices, and sales for 369 firms in a sample of developing countries that opened their stock markets to foreign investment during the late 1980s and early 1990s.

Stock market liberalization may seem like a narrow way of defining capital account liberalization relative to the broad indices of capital account openness employed in the literature, but there are several reasons why stock market liberalizations may be better suited to the task at hand. First, broad indices change gradually over time and therefore offer little variation with 
which to identify the effects of liberalization. Second, broad indices are based on the restrictions applied to an exhaustive list of possible capital account transactions. So, when the index does change, it is not evident which of the myriad possible restrictions has been eased. Without knowing which restriction has been eased, it is unclear how to map the change in the index to a well-articulated model for the purpose of empirical estimation.

Since measurement error reduces the statistical power of any regression, it is important to focus on natural experiments where the true variation in the data is large relative to any noise. Stock market liberalizations provide just such experiments, because they constitute a radical shift in the degree of capital account openness (Frankel, 1994). In addition to providing episodes of large changes in capital account openness, focusing narrowly on stock market liberalization offers another empirical advantage. Theory delivers clean predictions about the effect of stock market liberalization on the cost of capital and investment of the firms in the liberalizing countries. The predictions help confront the two opposing views of liberalization with new facts.

Figure 1 presents the first new fact. Firms experience investment booms in the aftermath of liberalizations. For the average firm in our sample, the growth rate of the real value of the capital stock exceeds its pre-liberalization mean by 3.8 percentage points in the first year after liberalization, 5.4 percentage points in the second year, and 2.2 percentage points in the third. The fact is uncontroversial. Its interpretation is not.

The boom in Figure 1 might be evidence of a discerning invisible hand allocating capital in response to fundamental changes brought on by liberalization. But Figure 1 might also be evidence of indiscriminacy writ large —overzealous firms collectively engaged in a wasteful investment binge. We attempt to distinguish between these two competing interpretations by analyzing whether the typical firm's post-liberalization investment decision reflects a rational 
response to the signals embedded in the stock price change that occurs when a country liberalizes (Bekaert and Harvey, 2000; Henry, 2000a; Stulz, 1999, 2003; Martell and Stulz, 2003). A change in a firm's stock price signals a change in one or both of the following fundamentals: (1) the firm's cost of capital; (2) the firm's expected future cash flow.

In the pristine world of theory, liberalization changes only the firm's cost of capital, and the change works through two channels. The first is a common shock - a fall in the aggregate risk-free rate as the country moves from financial autarky to world-market integration. The second is a firm-specific "beta" effect. With liberalization, the relevant benchmark for pricing the risk of individual stocks switches from the local stock market index to the world market index. Consequently, the equity premium falls for firms whose returns are less correlated with the world market than they are with the local market and vice versa.

All else equal, the common shock to the cost of capital increases the average investment rate of all firms. Given the common shock, the firm-specific shock implies that firms whose equity premia fall should invest even more than those whose premia rise.

In other words, the beta effect of liberalization is more than an asset-pricing result. A country's switch from financial autarky to optimal international risk sharing also requires the reallocation of physical capital in accordance with the change in the source of its aggregate risk. We use firm-level data to provide the first empirical test of this prediction.

Typical analyses of the gains from trade in risky assets (the beta effect) calibrate the hypothetical welfare losses associated with the lack of international risk sharing (Acemoglu and Zilibotti, 1997; Lewis, 1999, 2000; Obstfeld, 1994; Obstfeld and Rogoff, 1996, Chapter 5). In contrast, this paper examines whether an actual change in a country's ability to share risk internationally alters its allocation of productive resources in accordance with the predictions of 
neoclassical theory.

In the murky world of empirical work, stock market liberalizations coincide with other economic reforms such as the easing of trade restrictions that will primarily affect a firm's expected future cash flow. Therefore, it is important to control for the possibility that any postliberalization changes in investment may be driven by reform-induced changes in expected future cash flow. Using a simple open-economy model of Tobin's $Q$, we decompose firms' postliberalization changes in investment into: (1) changes in expected future cash flow; (2) the change in the risk-free rate; and (3) changes in equity premia. The cross-sectional variation in the data helps identify the economic and statistical significance of each effect.

Much of the cross-sectional evidence supports the discerning view of the invisible hand. The post-liberalization changes in investment are significantly correlated with changes in our measure of expected future cash flow. A 1-percentage-point increase in the growth rate of a firm's expected future cash flow predicts a 2.9- to 4.1-percentage-point increase in the growth rate of its capital stock, depending on the specification. The common shock to firms' cost of capital is also significant and accounts for a 2.3-percentage-point per-year increase in their capital stock growth. The invisible hand is not all discerning, however, for it pays no attention to risk: Firm-specific changes in equity premia have an economically trivial effect on changes in investment and are statistically insignificant in every specification.

In addition to providing the first attempt at using firm-level data to distinguish between opposing views of liberalization and to test theories of international risk sharing, the paper makes three additional contributions. First, it describes a valuable new source of firm-level data to economists conducting research on the real effects of economic reforms. Publicly available datasets such as Worldscope and Global Vantage contain virtually no data on firms in developing 
countries before the early 1990s and are therefore not suitable for studying the firm-level impact of the reforms that began in the mid 1980s. In contrast, the firm-level dataset used here spans the pre-and post reform period. ${ }^{1}$

Second, firm level data may provide a more transparent view of the channels through which liberalization affects real resource allocation than previous studies that use macro data (Bekaert et al., 2001; Henry, 2000b, 2003; Levine, 2001; Levine and Zervos, 1998). Instead of using aggregate investment data as a proxy for the investment of the firms affected by liberalization, we use the investment of only those firms that are listed on the stock market. Instead of using macro indicators as proxies for the effects of contemporaneous economic reforms on the expected future profitability of investment, we control directly for changes in firms' profitability with the real value of sales and earnings taken from their income statements.

Finally, firm-level data are less susceptible to the issue of endogeneity that clouds the interpretation of macro studies - do liberalizations drive investment booms or does causality run the other way round? A government may decide to liberalize a country's stock market because the economy-wide demand for capital is high, but the liberalization decision is plausibly exogenous to any given firm.

Yes, financially constrained firms with good investment opportunities might lobby the government to permit foreign entry, but it is far from obvious that financial constraints impede the investment decisions of our 369 firms. The firms in our sample are among the 100 largest manufacturing firms in each country, they all issue dividends, and their dividend issuance actually rises following liberalization. If anything, it appears that the firms we study stand to lose from the policy change, because liberalization may provide new sources of financing for

\footnotetext{
${ }^{1}$ Aitken and Harrison (1999) analyze the effects of FDI on the productivity of Venezuelan firms from 1976-89. But their data do not span the stock market liberalization period. Venezuela liberalized its stock market in 1990.
} 
their smaller, more financially constrained competitors.

\section{Time Series Facts About Firms, Liberalization, and Investment}

Between 1980 and 1994, the International Finance Corporation (IFC) collected annual balance sheet and income statement data for a maximum of the 100 largest publicly traded, nonfinancial firms in eleven developing countries: Argentina, Brazil, India, Jordan, Korea, Malaysia, Mexico, Pakistan, Thailand, Turkey, and Zimbabwe. When deciding in which countries it would collect data, the IFC employed two screening criteria: (1) quality data had to be available for a reasonably large number of firms; and (2) developing countries from each continent had to be represented. For several countries the sample begins after 1980 because the early years did not contain data of sufficiently high quality.

In order for a country in the IFC database to be included in our sample, it must satisfy one additional criterion. The IFC's data for the country must exist before and after the year in which the country liberalized its stock market. The before-and-after criterion reduces our sample to 369 firms spread across five countries: India, Jordan, Korea, Malaysia, and Thailand.

Table 1 uses relative stock market capitalizations to summarize the importance of the firms in the IFC sample for the five countries as a whole. The market capitalization of the 369 firms constitutes 40 percent of their total market capitalization. While the 40 -percent figure indicates that the firms in our sample account for a significant fraction of economic activity, the point should not be overstated because publicly traded corporations in developing countries make up a smaller fraction of the economic base than in developed countries.

The IFC database reports the nominal value of net fixed assets (the stock of property, plant, and equipment less depreciation) on an annual basis. In order to obtain the real growth 
rate of each firm's capital stock, the ideal adjustment procedure would deflate the percentage change in net fixed assets (NFA) by the rate of inflation of each firm's capital goods. Since no such capital goods data exist, we deflate using the Consumer Price Index in three steps. First we take the natural log of nominal NFA at time $t+1$ and subtract the natural log of NFA at time $t$. Second, we take the natural log of the Consumer Price Index (CPI) at time $t+1$ and subtract the natural $\log$ of the CPI at time $t$. Third, we subtract the second quantity from the first to produce the real growth rate of each firm's capital stock between $t$ and $t+1$.

\section{A. Firms Experience Investment Booms in the Aftermath of Liberalizations}

We use the data on real capital stock growth to evaluate the statistical significance of the investment spike in Figure 1. We do so by running a simple panel regression:

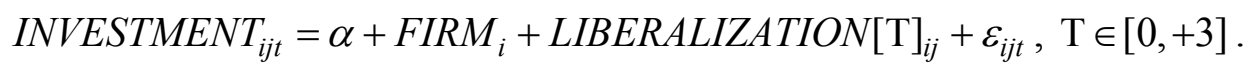

INVESTMENT $i j t$ is the real growth rate of the capital stock of firm $i$ in country $j$ in year $t$. FIRM $_{i}$ is a firm-specific dummy variable. The coefficient on the dummy variable LIBERALIZATION $[\mathrm{T}]_{i j}$ measures the average deviation of firm $i$ 's capital stock growth from its average over the 0 to +3 period. For example, LIBERALIZATION[0] $]_{i j}$ measures the average effect of liberalization on investment across all firms in year [0].

Since all firms in a given country are "clustered' around the same liberalization date, the covariances between individual firms' capital stock growth rate deviations may not be zero. If this is the case, the standard distributional assumptions about the error term, $\varepsilon_{i j t}$, no longer obtain. We adjust for clustering by allowing the off-diagonal elements in the variancecovariance matrix, to be different from zero. The estimation procedure also corrects for 


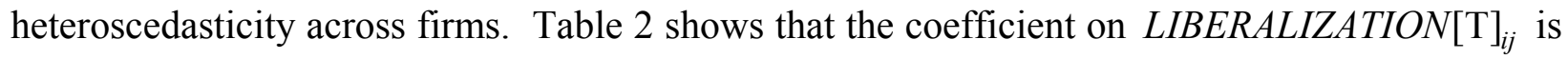
statistically significant at almost every time horizon. Column (1) presents estimates that include firm-fixed effects. Column (2) presents estimates that include country-fixed effects.

\section{B. Would a Control Group of Firms Exhibit the Same Spike in Investment?}

One should not look at the investment response of firms in liberalizing countries in isolation. If liberalizations coincide with a positive shock to the world business cycle, then the investment of firms in countries that do not liberalize may rise in concert with the investment of firms in countries that do. The ideal attempt to distinguish the effect of liberalization from that of an exogenous shock would compare the investment response of the firms in the liberalizing countries (Figure 1) with a control group - firms in a similar group of developing countries that did not liberalize. Unfortunately, we have no such data.

Since we cannot construct a proper control group, we adopt alternative measures to allow regression (1) to account for the effects of exogenous global shocks. Specifically, Column (3) of Table 2 presents estimates that include variables to control for the world business cycle. The controls are: the contemporaneous change in the growth rate of OECD industrial production; the three-month real US Treasury bill rate; the 10-year real US government bond rate. ${ }^{2}$ Column (4) re-estimates the country-fixed effects model, adding in the business cycle controls. The results in Column (4) show that the growth rate of the capital stock exceeds its pre-liberalization mean by 4.7 percentage points in years [0] and $[+1], 8.2$ percentage points in year $[+2]$, and 6.9 percentage points in year [+3]. Multiplying the investment deviations by the elasticity of output with respect to capital (about one-third), gives a rough estimate of the liberalization-induced

\footnotetext{
${ }^{2}$ Leads and lags of the control variables were also tried but did not yield significantly different results.
} 
growth deviations: 1.6 percentage points in years [0] and [+1], 2.7 percentage points in year $[+2]$, and 2.3 percentage points in year [+3]. Rough as they may be, these are large numbers with nontrivial implications for aggregate welfare given the size of the firms in our sample.

On the one hand, the results in Table 2 are not entirely surprising since aggregate capital stock growth rises by 1.1 percentage points per annum in the aftermath of liberalizations (Henry, 2003). On the other hand, it is not clear how much confidence we should have in the aggregate result, because the aggregate data consist of investment by publicly traded firms, non-publicly traded firms, and the government. Since liberalization most directly impacts the investment incentives of publicly traded firms, the firm-level effects documented here are more tenableand larger, as theory would predict. ${ }^{3}$

\section{C. Is There A Price Mechanism at Work?}

A rise in Tobin's $Q$ is a necessary (but not sufficient) condition for the investment boom to be a profit-maximizing response by firms to an increase in the market value of their installed capital. For each firm in the sample, we construct Tobin's $Q$ as follows. The numerator is the sum of the market value of equity and the book value of debt (current and long-term liabilities); we use book values of debt because the IFC database does not contain information on market values. The denominator is the book value of total assets.

The level of Tobin's $Q$ may not be directly comparable across countries, because of differences in accounting practices. For example, firms in India, Malaysia, and Jordan value

\footnotetext{
${ }^{3}$ It is important to note that the 5.4-percentage-point increase in the level of investment reported here also represents a larger change than the 22-percentage-point increase in the growth rate of investment documented in Henry (2000b). In other words, this paper documents changes in the first moment of capital stock growth while Henry analyzes second moments.
} 
assets using fair-market valuation in accordance with North American Generally Accepted Accounting Principles (GAAP). In contrast, Korea and Thailand rely on strict historic-cost accounting as in Germany and Japan (Booth et al., 2001). In light of these differences, we focus on the percentage changes in $Q$ that occur at liberalization. The last column of Table 1 shows that the average firm experiences a 46.1-percent jump in Tobin's $Q$ at liberalization. The jump in $Q$ does no harm to the discerning view of the invisible hand, but neither does it dismiss the objections of indiscriminate-hand adherents. Specifically, Figure 1 and the data on $Q$ beg the following question.

\section{D. Is the Investment Boom an Indiscriminate Response to a Stock Market Bubble?}

Since the jump in Tobin's $Q$ comes from the increase in stock prices that occurs at liberalization, it is important to remember that stock prices sometimes deviate from their fundamental values (Shiller, 1981, 2000). Ramping up investment in response to a stock price bubble may maximize someone's private objective function, but it can hardly be called efficient in a social welfare maximizing sense. ${ }^{4}$

For example, speculation about the new economy drove US stocks to unprecedented levels in the late 1990s. Many firms used the stock market bubble as a cheap means of raising capital to implement wasteful investment projects that resulted in billions of dollars of excess capacity. The surfeit of fiber optics cable laid by telecom firms is a particularly salient example. We now know that US firms continued investing en masse, even as the aggregate rate of return to capital was falling precipitously. If inefficient, bubble-driven investment has negative social consequences in the US where capital is relatively abundant, then it will be all the more costly in

\footnotetext{
${ }^{4}$ See Baker, Stein, and Wurgler (2003), Blanchard, Rhee and Summers (1993), Fischer and Merton (1984), and Stein (2003) for an extensive discussion of efficient investment when stock prices deviate from fundamentals.
} 
capital-scarce developing countries.

In order to assess whether liberalization fosters inefficient investment, we examine the ex-post rate of return to capital. For each firm, we compute the flow return to the stock of capital as the ratio of earnings before interest and taxes to the value of net fixed assets. After computing this ratio for each of the 369 firms, we take a simple average and call it the aggregate rate of return to capital.

Figure 2 shows that the rate of return to capital actually increases from an average of 16.0 percent per year in the pre-liberalization period (years -3 to -1 ) to 24.3 percent per year in the post-liberalization period (years +1 to +3 ). Whether managerial prescience or just dumb luck, it seems untenable to argue that liberalization stimulated wasteful investment when the rate of return to capital actually rises in the post-liberalization period.

While Figure 2 appears inconsistent with the notion of indiscriminate, bubble-driven investment, we would expect to see some decline in capital's rate of return as firms buy and install new machinery. Why does this not happen? The answer is that liberalizations coincide with important economic reforms that may increase total factor productivity, economic growth, and the profitability of investment (Frankel and Romer, 1999; Henry, 2003). Figure 3 demonstrates the point. The growth rate of real sales and real earnings both increase sharply during liberalization episodes.

There is no glaring evidence of inefficiency in the time series profiles of investment and the fundamentals. Yet for the invisible hand to be efficient, it must be discerning not only in the time series but also in the cross section. In turn, cross-sectional efficiency requires that firms' post-liberalization investment decisions systematically reflect the signals about fundamentals that are embedded in the stock price changes that occur at liberalization. Whether or not this is 
the case is the question to which we now turn.

\section{Cross-Sectional Facts About Firms, Liberalization, and Investment}

If markets are efficient, then changes in stock prices are a summary statistic for changes in the fundamentals. To the extent that the responses of firms' stock prices to liberalization reflect news about the present value of future cash flow, those price responses should have some predictive power for the post-liberalization changes in investment. To that end, let LIBERALIZATIONRETURN $_{i}$ denote the percentage change in firm $i$ 's real stock price, defined as the percentage change in the liberalization year.

Analyzing firms' investment responses to liberalization also requires a measure of the unexpected growth rate of their capital stocks relative to some benchmark. All else equal, in the instant before the news of liberalization arrives, the pre-liberalization mean of a firm's capital stock growth rate is a reasonable forecast for its expected future growth rate. Accordingly, define the variable INVESTMENTDEVIATION $N_{i t}$ as the growth rate of firm $i$ 's capital stock in year $t$ minus its average pre-liberalization growth rate (calculated over the years -3 to -1 ).

If the discerning invisible hand view is correct, then INVESTMENTDEVIATION ${ }_{i t}$ should be positively related to LIBERALIZATIONRETURN ${ }_{i}$. If the indiscriminate view is correct, there should be no systematic relation between the two variables. Equation (2) shows that the coefficient on LIBERALIZATIONRETURN $N_{i}$ has the predicted sign and is significant at the one percent level (standard errors in parentheses; adjusted R-Squared=0.01; $\mathrm{N}=1185$ ):

$$
\text { INVESTMENTDEVIATION }_{i t}=0.001+0.056 \text { LIBERALIZATIONRETURN }_{i}, t \in[0,+3]
$$

The low value of R-squared indicates a lot of unexplained variation and might be interpreted as evidence of indiscriminacy. But it is important to remember that the principal objective of 
empirical work is to obtain dependable estimates of the true regression coefficients, not to achieve high values of R-squared (Gujarati, 1988, p. 186).

Bearing that caveat in mind, equation (2) provides reasonable support for the theory. On average, the larger the impact of liberalization on a firm's stock price, the larger is its postliberalization increase in capital stock growth. More importantly, a simple calculation illustrates that the simple correlation between the change in investment and the stock price change is economically significant. The average value of LIBERALIZATIONRETURN $N_{i}$ in our sample is 51 percent. So, equation (2) predicts that the growth rate of the average firm's capital stock will exceed its pre-liberalization mean by 2.9 percentage points ( 51 percent times 0.056 ) in each of the years $[0,+3]$. The implication of this estimate for output growth is not small—about one percentage point per year.

\section{A. Do Changes in Future Growth Opportunities Drive the Changes in Investment?}

In the absence of bubbles (Section 1D), a change in a firm's stock price signals a change in the firm's expected future earnings or its cost of capital. Therefore, it is important to understand whether the post-liberalization changes in investment are correlated with the "news" in expected future growth opportunities. To that end, define FUTUREGROWTH ${ }_{i \tau}$ as the growth rate of firm $i$ 's sales in year $\tau$ (where $\tau$ runs from +1 to +3 ) minus the average growth rate of

firm $i$ 's sales in years -3 to -1 . Equation (3) shows that INVESTMENTDEVIATION $N_{i t}$ is

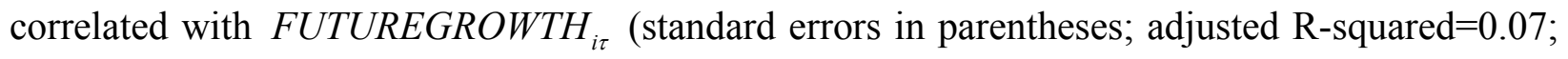
$\mathrm{N}=1292)$ :

$$
\begin{aligned}
\text { INVESTMENTDEVIATION }_{i t}= & 0.023+0.295 \text { FUTUREGROWTH }_{i \tau}, t \in[0,+3] . \\
& (0.009)(0.029)
\end{aligned}
$$


Again, the economic significance of the unconditional correlation between the left- and righthand-side variables is nontrivial. News that FUTUREGROWTH for firm $i$ will be 10 percentage points higher predicts that its capital stock growth will deviate from its pre-liberalization mean by 2.95 percentage points.

It is natural to ask whether the predictive power of sales growth for investment during liberalization episodes differs from the predictive power of sales growth for investment at any generic point in time. In order to address the issue, we estimate the following specification:

$$
\begin{aligned}
& \text { INVESTMENT }_{i j t}=\alpha+\text { CNTRY }_{j}+\beta_{1} \text { SALESGROWTH }_{i j t} \\
& +\beta_{2} \text { SALESGROWTH }_{i j t} * \text { LIBERALIZATION }_{i j t}+\varepsilon_{i j t} .
\end{aligned}
$$

Note that the variable INVESTMENT $T_{i j t}$ is the absolute growth rate of the real capital stock, not deviations of the growth rate from the mean as in equation (3). Similarly, SALESGROWTH ${ }_{i j t}$ is the absolute growth rate of real sales. The reason for not using deviations is that equation (4) attempts to estimate the behavior of investment over the entire sample - not just the postliberalization period — and deviations from the mean over the entire sample will, by definition, be equal to zero.

Equation (4) is similar in spirit to the estimations in Wurgler (2000). Wurgler's crosssectional exercise examines whether the responsiveness of investment to profitability is higher in countries with more developed financial systems. We ask whether liberalization changes the responsiveness of investment to changes in profitability, taking the country's financial development as given. It would be useful to investigate how a country's financial development affects the ability of firms to respond to liberalization, but with only five countries in our sample there is not enough cross-country variation to address the issue. 
If the responsiveness of investment to sales at a generic time, $t$, is the same as when $t$ is a liberalization year, then the coefficient on SALESGROWTH $_{i j t} *$ LIBERALIZATION $_{i j t}$ should not be significant. Table 3 shows that both the coefficient on SALESGROWTH $H_{i j t}$ and the interaction term are significant. The coefficient on SALESGROWTH $_{i j t} * L_{I B E R A L I Z A T I O N} N_{i j t}$ ranges from 0.056 to 0.21 and is statistically significant at the 1 percent level.

The coefficient on SALESGROWTH $_{i j t} *$ LIBERALIZATION $_{i j t}$ may be significant because firms lack access to external finance. The increase in the growth rate of sales that occurs at liberalization is unusually large (Figure 3); this shock to profitability may simply provide firms a cash windfall with which to finance projects that they could not implement in the preliberalization period. We now turn to a more thorough investigation of the possibility that the firms in the sample face financial constraints.

\section{A.1 What if Capital Markets are Not Frictionless?}

In a frictionless capital market world, only expected future growth opportunities should matter for investment. If liberalization bodes well for the future, then investment should increase, regardless of the firm's current cash flow. There is ample evidence, however, that current cash flow exerts a significant influence on investment (Fazzari, Hubbard, and Petersen, 1988; Hubbard, 1998). So, an alternative view is that investment rises because liberalizations ease financing constraints by increasing the amount of cash in the firm.

In order to examine whether INVESTMENTDEVIATION ${ }_{i t}$ is significantly related to current cash flow we construct a variable called CASHFLOWDEVIATION, which is defined as the growth rate of firm $i$ 's sales in year $t$ minus the average growth rate of its sales in years -3 to -1. Equation (5) shows that the coefficient on CASHFLOWDEVIATION is the same order of 
magnitude as the coefficient on FUTUREGROWTH in equation (3) and is statistically significant at the 1 percent level (standard errors in parentheses; adjusted R-squared $=0.01 ; \mathrm{N}=1292$ ):

$$
\text { INVESTMENTDEVIATION }_{i t}=0.038+0.221 \text { CASHFLOWDEVIATION }_{i t}, t \in[0,+3] .
$$

But the interpretation of the coefficient on CASHFLOWDEVIATION is less straightforward.

If firms face financing frictions, investment will be sensitive to current cash flow. Importantly, however, the converse of the preceding statement need not be true. Sensitivity of investment to current cash flow need not imply that firms face financial constraints. Firms' investment may be sensitive to cash flow, even in the absence of financial constraints that impede their ability to implement optimal investment decisions (Kaplan and Zingales, 1997, 2000; Stein, 2003).

A number of models of corporate investment in the presence of capital market frictions can account for the significant coefficient on CASHFLOWDEVIATION in equation (5), and an attempt to distinguish between all of the competing explanations lies beyond the scope of this paper. ${ }^{5}$ Instead we ask the question most germane to the task at hand: Is there any evidence that a lack of access to external finance impedes the invisible hand from optimally allocating investment? While access to external finance would not seem to be an issue for the 100 largest manufacturing firms in a country—-large established firms with lots of tangible assets tend to have access to credit—we examine several variables that speak directly to the issue. ${ }^{6}$

Begin with dividends. A Firm that pays dividends could invest more by cutting dividends, so it seems unlikely that a dividend-paying firm suffers from capital rationing (Lang

\footnotetext{
${ }^{5}$ See Stein (2003) for a review of the literature on capital market imperfections and corporate investment.

${ }^{6}$ Our analysis of access to external finance is similar in spirit to that of Johnson, McMillan and Woodruff (2002).
} 
and Stulz, 1994). All of the firms in our sample pay dividends. Furthermore, there is a significant increase in dividend issuance following liberalization (Row 1 of Table 4). Again, it seems unlikely that capital-constrained firms would, on average, increase dividends at the very moment investment opportunities are improving (Figures 2 and 3). Next, turn to debt. All of the firms in our sample have long-term debt, which again does not suggest an inability to access external finance.

To provide a more general picture of the extent to which the firms in our sample use external sources to finance investment, Table 4 lists several indicative variables: dividends, longterm debt, total external finance, retained earnings, and equity. We construct the ratio of the change in each variable to the change in the stock of net fixed assets (investment). We then calculate the average value of the ratio before liberalization, the average value after liberalization, and test whether the difference between the two averages is statistically significant.

Table 4 shows that reliance on external finance rises in the aftermath of liberalizations, but not significantly so. Furthermore, there is a significant increase in reliance on internal funds. The evidence in Table 4 taken together with the evidence in Section 2A suggests that the firms in our sample increase investment when future growth prospects improve, but they also increase investment when they have a lot of cash. These facts are roughly consistent with what we know about the investment behavior of firms in developed countries (Stein, 2003). Again, sorting through all the alternative explanations of these facts lies beyond our ambit. Here is the central point: While financial constraints are surely an issue for some firms in the countries we study, there is no glaring evidence that a lack of access to external finance severely impedes the investment decisions of the 369 firms in our sample. 


\section{B. Do Changes in Risk Sharing Drive the Changes in Investment?}

Shocks to current and future growth opportunities are only part of the story. Liberalization may also change a firm's investment, because it alters the firm's cost of capital. In turn, recall that liberalization affects the cost of capital through two channels: a common shock to the aggregate risk-free rate and a change in the firm-specific equity premium (risk sharing).

For technical reasons, we defer analysis of the common shock until Section 3. Here, we focus on whether the raw data provide any evidence that the invisible hand allocates investment in accordance with changes in risk sharing. To do so, we need a measure of risk sharing. Define the variable $\operatorname{DIFCOV}_{i}$ as the historical covariance of firm $i$ 's stock return with the local market minus its historical covariance with the world stock market. The theoretical justification for DIFCOV also comes in Section 3, but intuitively, DIFCOV captures the beta effect to which the introduction alludes - the potential diversification benefits that firm $i$ provides the representative foreign investor.

If the invisible hand is discerning, high $D I F C O V$ firms should experience faster capital stock growth than low DIFCOV firms in the aftermath of liberalizations. The data, however, are more consistent with the indiscriminate view (standard errors in parentheses; adjusted Rsquared $=-0.005 ; \mathrm{N}=1080)$ :

$$
\text { INVESTMENTDEVIATION }_{i t}=0.026+0.12 \text { DIFCOV }_{i} .
$$

The coefficient on DIFCOV is statistically insignificant. More importantly, the coefficient is economically trivial. To get a sense of what trivial means, multiply the coefficient on $D I F V C O V$ (0.12) by the average value of $D I F C O V$ for the firms in the sample (0.015). This calculation 
shows that the average annual effect of risk sharing on the typical firm's capital stock growth is 0.0018 or 0.18 percentage points, which means that the effect on firm output growth is roughly 0.06 percentage points per annum-trivial.

Discerning invisible hand advocates might argue that the failure of risk (DIFCOV) to matter for the allocation of physical capital might come about not because the invisible hand is indiscriminate, but because firms face financial constraints that hinder their ability to respond to the liberalization-induced stock price signals. The problem with this explanation is that we have just seen (Section 2A.1) that there is little evidence to suggest that the firms in our sample are financially constrained. Furthermore, there are large increases in investment following liberalization; it is just that $D I F C O V$ does not guide the increases. It is not clear why financial constraints would permit a firm to substantially increase its investment, but prevent it from doing so in a way that incorporates changes in risk.

\section{B.1 Is the Capital Asset Pricing Model (CAPM) the Relevant Risk-Sharing Benchmark?}

Characterizing the invisible hand's insensitivity to risk as evidence of indiscriminacy may seem unjust, because the risk-sharing hypothesis is a hollow straw man. Since there is little evidence to suggest that levels of expected stock returns in the US vary cross-sectionally according to the degree of firms' exposure to aggregate covariance risk, the notion that firms in developing countries allocate physical investment in accordance with the CAPM seems to fly in the face of all common sense.

Yet there is no hiding from economic theory, even for the most practical of considerations (Keynes, 1936, p. 383-84). All major studies of the gains to trade in risky assets lean heavily on the intuition that covariance risk can be priced (Lewis, 1999, 2000; Obstfeld, 
1994; Obstfeld and Rogoff, 1996, Chapter 5). Whether the asset pricing model uses a partial equilibrium or general equilibrium consumption-based approach, all of these papers are predicated on the validity of beta-like intuition: The potential gains to international risk sharing stem from the extent to which trade in risky assets permits individuals to smooth covariance risk.

When a liberalization occurs, the relevant benchmark for pricing covariance risk switches from the local stock market index to the world market index. New evidence suggests that the changes in firms' stock returns that occur during liberalizations reflect these changes in covariance risk (Chari and Henry, 2004). While the stock price changes at liberalization may convey information about changes in risk sharing, the more pressing economic question is whether investment also responds to changes in risk sharing. Optimal smoothing of production risk in an open-capital-market world requires the reallocation of physical capital in accordance with changes in covariance risk. We provide a small step forward by using firm-level data to provide the first empirical test of this prediction.

\section{A Simple Model of Firm-Level Investment, Stock Prices, and Liberalization}

This section of the paper generates empirically testable, cross-sectional predictions about firm-level investment, stock prices, and liberalization. It does so by analyzing what happens to the investment of an all equity-financed firm when the country in which that firm resides moves from a regime where foreigners are not permitted to own domestic shares and domestic residents cannot invest abroad, to one where all stocks are fully tradable. ${ }^{7}$ We begin by making all of the standard assumptions that are necessary for the CAPM to hold. For expositional convenience, we also assume that all investors have an identical coefficient of relative risk aversion $\gamma$. The

\footnotetext{
${ }^{7}$ The results do not hang on this assumption. Chari and Henry (2004) address alternative assumptions.
} 
frictionless capital markets framework highlights the key margins at which liberalization affects firms' investment decisions, but the empirical analysis in Section 4 incorporates the possibility of financial frictions discussed in Section 2A.1.

\section{A. Firm-Level Investment Before the Liberalization}

Consider a small country in financial autarky. The goal is to use the standard firm-level investment equation

$$
\left(\frac{I}{K}\right)_{i}=a+b Q_{i}
$$

to show how liberalization changes a firm's desired investment. Assume that the firm is 100 percent equity financed so that its capital market value equals the stock market value of its equity. Let $\tilde{\pi}_{i}$ denote the firm's stochastic cash flow, which is expected to grow exponentially at the rate $g_{i}$. Since the stock market value of the firm is the present discounted value of its expected future cash flow, we may express Tobin's formula, $Q_{i}=\frac{V_{i}}{K_{i}}$, in a more primitive form:

$$
Q_{i}=\frac{\bar{\pi}_{i}}{K_{i}\left[r+\theta_{i}-g_{i}\right]}
$$

Where $K_{i}$ denotes the number of units of firm $i$ 's capital, $r$ is the economy's risk-free interest rate, $\bar{\pi}_{i}$ the expected value of $\tilde{\pi}_{i}$, and $\theta_{i}$ the risk premium on firm $i$ 's stock.

\section{B. Firm-Level Investment After the Liberalization}

Now suppose that the country opens its stock market to the rest of the world and also allows its residents to invest abroad. Equations (7) and (8) show that liberalization affects investment through its effect on the fundamentals. Interest rates, risk premia, and expected 
future growth rates may all change instantaneously in response to the news of liberalization. In contrast, the stock of capital, $K_{i}$, adjusts more slowly because it takes time to buy and install new machines. Hence, define "on-impact" as a period of time that is long enough for asset prices to adjust to liberalization but too short for the capital stock to do so as well, and let $Q_{i}^{*}$ denote the on-impact value of $Q$ for firm $i$.

A little bit of algebra shows that the on-impact change in $Q$ may be written as:

$$
\Delta Q_{i}^{*} \equiv Q_{i}^{*}-Q_{i}=\lambda_{i}\left[\left(r-r^{*}\right)+\left(\theta_{i}-\theta_{i}^{*}\right)+\left(g_{i}^{*}-g_{i}\right)\right]
$$

Where $r^{*}, \quad \theta_{i}^{*}$ and $g_{i}^{*}$ are the post-liberalization values of the fundamentals and $\lambda_{i}=\frac{\bar{\pi}_{i}}{K_{i}\left[\left(r+\theta_{i}-g_{i}\right)\left(r^{*}+\theta_{i}^{*}-g_{i}^{*}\right)\right]}$. The on-impact change in $Q$ will drive the subsequent adjustment in the firm's capital stock. Since $Q$ has changed, the capital stock must also adjust to reestablish equilibrium. Specifically, the liberalization-induced change in the firm's desired investment, which we denote $\Delta\left(\frac{I}{K}\right)_{i}^{*}$, must equal $\Delta Q_{i}^{*} \cdot{ }^{8}$ In other words, the post-liberalization change in investment can be written as:

$$
\Delta\left(\frac{I}{K}\right)_{i}^{*}=\lambda_{i}\left[\left(r-r^{*}\right)+\left(\theta_{i}-\theta_{i}^{*}\right)+\left(g_{i}^{*}-g_{i}\right)\right]
$$

Now, the pre- and post-liberalization risk premia $\left(\theta_{i}\right.$ and $\left.\theta_{i}^{*}\right)$ are not directly observable, so it takes one more step to deliver an empirically testable equation. Recall that under the CAPM, $\theta_{i}=\left\{\operatorname{Cov}\left(R_{i}, R_{M}\right) / \operatorname{Var}\left(R_{M}\right)\right\} \bar{R}_{M}$, where the variable $R_{M}$ is the excess return on the

\footnotetext{
${ }^{8}$ Adjustment costs may deter firms from installing capital until $Q$ returns to its pre-liberalization level, but the direction and magnitude of the change in the capital stock will still depends on the on-impact change in $Q$.
} 
domestic market portfolio, $\bar{R}_{M}$ its expected value, and $\operatorname{COV}\left(R_{i}, R_{M}\right)$ the historical covariance of firm $i$ 's stock return with the local market. Similarly, $\theta_{i}^{*}=\left\{\operatorname{Cov}\left(R_{i,} R_{W}\right) / \operatorname{Var}\left(R_{W}\right)\right\} \bar{R}_{W}$, where the subscript $w$ indexes the world market portfolio. Using these definitions and a bit of algebra, it can be shown that $\theta_{i}-\theta_{i}^{*}=\gamma\left[\operatorname{COV}\left(R_{i}, R_{M}\right)-\operatorname{COV}\left(R_{i}, R_{W}\right)\right]=\gamma \operatorname{DIFCOV} .{ }^{9}$ Finally, using the definition of $D I F C O V$ we may rewrite equation (10) as

$$
\Delta\left(\frac{I}{K}\right)_{i}^{*}=\lambda_{i}[\underbrace{\left(r-r^{*}\right)+\gamma \text { DIFOV }_{i}}_{\text {Change in Cost of Capital }}+\overbrace{\left(g_{i}^{*}-g_{i}\right)}^{\text {Change in Growth Rate of Earnings }}]
$$

The three terms in brackets on the right-hand-side of equation (11) highlight the forces that drive the change in investment following the liberalization.

The first term, $\left(r-r^{*}\right)$, has no subscript because it captures the effect of the common shock to the cost of capital. The second term, $\operatorname{DIFCOV}_{i}$, does have a subscript, because it measures the impact of the firm-specific change in risk sharing (the beta effect). Given the first term, the second implies that high DIFCOV firms will experience a larger fall in the cost of capital (and therefore more investment) than low DIFCOV firms. The third term, $\left(g_{i}^{*}-g_{i}\right)$, shows that larger the increase in the growth rate of a firm's expected future cash flow, the greater the change in its post-liberalization investment.

\section{Estimating the Investment Response: Methodology and Empirical Results}

The $\lambda_{i}$ term in front of the brackets in equation (11) is a firm-specific scaling factor that has some technical implications for empirical estimation. If the $\lambda_{i}$ 's were observable, we could

\footnotetext{
${ }^{9}$ For a detailed derivation see Chari and Henry (2004).
} 
transform the terms in brackets to yield an equation with constant coefficients. The problem is that the $\lambda_{i}$ 's are not observable. In the absence of observable $\lambda_{i}$ 's, it would seem natural to estimate equation (11) with a random coefficients model that accounts for the firm-specific regression coefficients on sales growth, the common shock, and $\mathrm{DIFCOV}_{i}$.

The problem with random coefficients estimation is that it requires time variation in all of the right-hand-side variables, but $D I F C O V$ is a purely cross-sectional variable. For each firm, $\operatorname{DIFCOV}_{i}$ is simply one number-the historical covariance of firm $i$ with the local market minus its historical covariance with the world market. Since we cannot estimate (11) using random coefficients, we begin with a panel specification that ignores the scale effect. Section 4D shows that ignoring the scale effect is inconsequential, so we estimate the following:

$$
\begin{aligned}
& \text { INVESTMENTDEVIATION }_{i j t}=\alpha+\text { CNTRY }_{j}+\beta_{1} \text { CASHFLOWDEVIATION }_{i j t}+ \\
& \beta_{2} \text { FUTUREGROWTH }_{i j t}+\beta_{3} \text { DIFCOV }_{i j}+\varepsilon_{i j t}, t \in[0,+3] .
\end{aligned}
$$

Equation (12) estimates the effect of changes in $Q$ on changes in investment and captures all of the qualitative features that are present in the structural decomposition of equation (11). The left-hand-side variable in (12), INVESTMENTDEVIATION $N_{i j t}$, is the deviation of firm i's capital stock growth from its firm-specific mean. The subscript $t$ indicates the time variation in that variable over the years $[0,+3]$. The constant $\alpha$ measures the common shock to the cost of capital. The country-specific dummy variable $C N T R Y_{j}$ accounts for the possibility that the magnitude of the common shock differs across countries.

Although CASHFLOWDEVIATION $N_{i j t}$ does not appear in the theoretical decomposition of equation (11), we include it in specification (12) because of the evidence in Section 2 that current sales is related to investment. FUTUREGROWTH ${ }_{i j t}$ controls for firm-specific shocks to 
sales growth. It bears repeating that by definition FUTUREGROWTH ${ }_{i j t}$ controls for all shocks to cash flows: those incidental to stock market liberalization, those resulting from the effects of other reforms such as trade liberalization, and those due to any other unexpected shocks. $D_{I F C O V}{ }_{i j}$ controls for changes in firm-specific equity premia.

The panel regression pools all firms together, so even though $D_{I F C O V_{i j}}$ does not vary over time for any given firm, it does vary across firms for any given time period. Equation (12) uses precisely this cross-firm variation for any given time period to estimate the coefficient on $D I F C O V_{i j}$. In contrast to the coefficient on $D I F C O V_{i j}$, equation (12) estimates the beta coefficient on FUTUREGROWTH $H_{i j t}$ by making use of both the time series variation in sales growth within a firm and the cross-sectional variation in sales growth across firms. To see this, simply note that the variable FUTUREGROWTH $H_{i j t}$ has both a firm and a time subscript. As in Section 1A, we control for the clustering of firms around a common liberalization date.

\section{A. Results: Changes in Growth and the Common Shock Matter, Changes in Risk Do Not}

Table 5 reports the estimations of equation (12). All the regressions include countryfixed effects. Column (1) reports the regression of INVESTMENTDEVIATION $N_{i j t}$ on a constant and country-fixed effects with no other controls. The coefficient on the constant is 0.041 and is significant at the one-percent level.

Column (2) reports the regression of INVESTMENTDEVIATION ${ }_{i j t}$ on a constant and FUTUREGROWTH $_{i j t}$ and CASHFLOWDEVIATION $N_{i j t}$. The coefficient on CASHFLOWDEVIATION $_{i j t}$ is 0.229 and also significant at the one-percent level. The coefficient on FUTUREGROWTH $H_{i j t}$ is 0.315 and significant at the one-percent level. Again, the 
estimate of the constant, 0.019 , is economically and statistically significant.

Column (3) of Table 5 reports the regression of INVESTMENTDEVIATION $N_{i j t}$ on a constant and DIFCOV $V_{i j}$. The constant in this specification is 0.028 and significant at the onepercent level. The coefficient on $D I F C O V_{i j}$ is positive, as predicted by the theory, but the coefficient is now even smaller $(0.037)$ than the effect in the raw data $(0.12)$ and is statistically insignificant.

Column (4) reports the results from the full decomposition suggested by equation (11). The coefficient on CASHFLOWDEVIATION is 0.316. The coefficient on FUTUREGROWTH $H_{i j t}$ is 0.287 . Both coefficients are significant at the one-percent level. The constant is not significant in this regression. DIFCOV continues to be economically and statistically insignificant.

\section{B. Are Changes in the Cost of Capital Irrelevant for Changes in Investment?}

While the coefficient on $D_{I F C O V}$ in Columns 1 through 4 of Table 5 is trivial, the constant is significant in 3 of the 4 regressions. So, there is some evidence that the common shock to the cost of capital affects the post-liberalization changes in investment. Having said that, interpreting a significant constant as the impact of the common shock is not without difficulty. In theory, the constant captures the common shock, but in practice it might be picking up the effect of an unobserved regime shift that has nothing to do with a change in the cost of capital - a spike in investment due to some omitted variable that is important for investment but lies outside of our model, for example.

In order to scrutinize whether changes in the cost of capital really matter, Column (5) of 
Table 5 reports the results of a regression of INVESTMENTDEVIATION $N_{i j t}$ on a constant, FUTUREGROWTH $_{i j t}$, CASHFLOWDEVIATION $_{i j t}$, and LIBERALIZATIONRETURN ${ }_{i j}$. The logic of this regression is straightforward. Theory says that $\operatorname{LIBERALIZATIONRETURN~}_{i j}$ is driven by changes in expected future cash flows and the cost of capital. Since we are controlling for changes in cash flows with FUTUREGROWTH ${ }_{i j t}$ and CASHFLOWDEVIATION ${ }_{i j t}$, a significant coefficient on LIBERALIZATIONRETURN $N_{i j}$ in this regression would suggest a significant effect of the cost of capital on investment.

Column (5) shows that the coefficient on LIBERALIZATIONRETURN $N_{i j}$ is 0.030 and significant at the 5 percent level. This is a smaller number, 0.057 , than the coefficient on LIBERALIZATIONRETURN $_{i j}$ in equation (1), but it is still economically significant and suggests that firms' post-liberalization changes in investment are significantly related to changes in their overall cost of capital.

It is also important to note that the constant is no longer significant in the specification reported in Column (5). If the significant constant in columns (1) through (3) reflects some spurious regime shift in investment that is unrelated to a change in the cost of capital, then the constant should be unaffected by the inclusion of LIBERALIZATIONRETURN $N_{i j}$ on the righthand-side, but this is not the case. Column (6) reports the results from an additional regression that includes only LIBERALIZATIONRETURN ${ }_{i j}$ on the right-hand side; the numbers show that the coefficient on LIBERALIZATIONRETURN ${ }_{i j}$ is significant, the constant is not.

To confirm that risk sharing plays no role in guiding the post-liberalization allocation of investment Column (7) reports the results of a final specification. We regress 
INVESTMENTDEVIATION $_{i j t}$ on a constant, FUTUREGROWTH ${ }_{i j t}$, DIFCOV $_{i j}$ and LIBERALIZATIONRETURN $_{i j}$. The coefficient on LIBERALIZATIONRETURN ${ }_{i j}$ is 0.042 and significant at the 5-percent confidence level. The coefficient on FUTUREGROWTH ${ }_{i j t}$ is 0.317 and significant at the one-percent level. The coefficient on $D I F C O V_{i j}$ remains economically and statistically insignificant.

\section{C. Robustness: Random Coefficients and a New Definition of Investment Deviations}

The regression specifications in Table 5 do not adjust for firm-specific scale effects. In order to examine the robustness of not doing so, we re-estimate a subset of the results using the following random coefficients specification:

$$
\begin{aligned}
& \text { INVESTMENTDEVIATION } N_{i j t}=\alpha+\text { CNTRY }_{j}+\beta_{i} \text { FUTUREGROWTH }_{i j t}+\varepsilon_{i j t}, \\
& t \in[0,+3] .
\end{aligned}
$$

Equation (13) differs from equation (12) in two important ways. First, DIFCOV $V_{i j}$ and LIBERALIZATIONRETURN $N_{i j}$ are not included on the right-hand-side because they are purely cross-sectional variables and Random coefficients requires time variation. Second, the coefficient on FUTUREGROWTH $H_{i j t}, \beta_{i}$, is now firm specific.

Random coefficients estimation calculates the coefficient on FUTUREGROWTH $H_{i j t}$ using a two-step procedure. The first step adjusts for firm scale effects in the following fashion. For a given firm, the random coefficients procedure uses the time variation in FUTUREGROWTH $H_{i j t}$ to generate an Ordinary Least Squares (OLS) regression coefficient. This coefficient measures the firm-specific effect of FUTUREGROWTH $H_{i j t}$ on investment. The first step is then repeated for each firm in the sample. The second step uses all the firm-specific OLS estimates to create a 
single estimate of the effect of the right-hand-side variable on investment. It does so by using the $\lambda_{i}$ 's from equation (11) to generate a weighted average of the firm-specific OLS coefficients.

If scale effects are important, then the random coefficients estimate of the coefficient on FUTUREGROWTH $H_{i j t}$ should differ significantly from the earlier estimate of the coefficient on FUTUREGROWTH $H_{i j t}$ that does not adjust for scale effects (Column (2) of Table 5). This is not the case. The coefficient on FUTUREGROWTH $H_{i j t}$ using random coefficients is 0.167 and significant at the 1-percent level. Similarly, the constant is 0.015 and significant at the 5-percent level.

It is important to ask whether our measure of capital stock growth deviations is sensitive to the choice of the pre-liberalization window. If countries liberalize in response to crises or recessions, then using the three years immediately preceding the liberalization as a benchmark may overstate the abnormal growth rate of the capital stock in the post-liberalization period. Table 6 replicates all of the results in Table 5 using a new left-hand-side variable called INVESTMENTDEVIATIONI $1_{i j t}$, which is defined as the growth rate of firm $i$ 's capital stock in year $t$ minus its average growth rate in the entire pre-liberalization period. The results in Table 6

are very similar to those in Table 5. The variables CASHFLOWDEVIATION ${ }_{i j t}$ and FUTUREGROWTH $H_{i j t}$ are always significant, the constant and the coefficient on LIBERALIZATIONRETURN $N_{i j}$ are often significant, and DIFCOV $V_{i j}$ never matters.

\section{Why Does the Invisible Hand Ignore Risk?}

The coefficient estimates on $D I F C O V_{i j}$, are economically trivial and statistically insignificant in every regression, which suggests that risk sharing has negligible empirical 
implications for investment. But, in fairness to the discerning invisible hand view, it is possible that the significance of risk sharing is masked by measurement error.

For example, when countries liberalize, some publicly listed firms become eligible for foreign ownership (investible), while others remain off limits (non-investible). Data from the IFC's Emerging Markets Database show that $D I F C O V$ robustly explains the change in the cost of capital for investible firms, but is never significant for the non-investible ones (Chari and Henry, 2004). Therefore, it is possible that changes in investment are significantly correlated with $D I F C O V$ for the investible firms, but the relation is masked because the investible and noninvestible firms are grouped together in our sample.

The investible and non-investible firms are grouped together in our sample, because the IFC Corporate Finance Database - the source of all the capital stock data — does not identify investible and non-investible firms. The Emerging Markets Database distinguishes between investible and non-investible firms, but it contains no capital stock data. By using the information in the EMDB, we were able to identify 61 investible and 28 non-investible firms in the IFC Corporate Finance database. We then redid the entire battery of tests for risk sharing on this sample of 89 firms. Again, DIFCOV was never significant.

Returning to the full sample, we conducted three additional tests for evidence of risk sharing. First, we constructed a new risk-sharing variable called DIFCOV1 using the growth rate of real earnings instead of stock returns. Specifically, DIFCOV1 is defined as the historical covariance of firm $i$ 's real earnings growth with the aggregate growth rate of real earnings on the local market, minus the historical covariance of firm $i$ 's real earnings growth with the aggregate growth rate of real earnings on the S\&P 500. Second, we sorted the firms by the sign of DIFCOV. Firms for whom DIFCOV is greater than zero we label DIFCOVPOSITIVE; firms for 
whom DIFCOV is less than zero we label DIFCOVNEGATIVE. Third, we ranked the firms in descending order of the magnitude of DIFCOV. Firms in the top 20 percent of the distribution we label DIFCOVHIGH; those in the bottom 20 percent we label DIFCOVLOW. After constructing our three new risk-sharing variables, we reproduced the correlations in equation (6) using the three new measures of risk sharing. None of the three new variables produced significant results.

The result that changes in risk sharing do not guide the allocation of real resources stands in sharp contrast with the predictions of standard models in open-economy macroeconomics. By enabling domestic residents to engage in international risk sharing, capital account liberalization should encourage firms to implement high growth projects that were too risky to adopt in autarky (Obstfeld, 1994).

The expression for the liberalization-induced change in a firm's cost of capital provides one possible explanation for why the data do not support this prediction:

$$
\Delta \rho_{i}=\left(r-r^{*}\right)+\gamma \text { DIFCOV }_{i} .
$$

Suppose that liberalization reduces the risk-free rate by 10 percentage points and that the coefficient of relative risk aversion, $\gamma$, takes on a value of 2 . Since the average value of DIFCOV $_{i}$ in our sample is 0.015 , the average firm-specific change in the cost of capital will be 3 percentage points ( 2 times 0.015 ), which means that the total fall in the cost of capital is 13 percentage points. The common shock, however, accounts for roughly 80 percent of the change. This simple numerical example illustrates a fundamental point. If the common shock dominates the firm-specific shocks then changes in the cost of capital will display little crosssectional variation and $\mathrm{DIFCOV}_{i}$ will not have much explanatory power. 


\section{Conclusion}

The time series facts support the view that liberalization permits capital to move efficiently across countries. The cross-sectional evidence, on the other hand, is mixed. Changes in investment are significantly related to changes in cash flows, but if more extensive firm-level data were available they might reveal more evidence of indiscriminacy. Our dataset consists only of firms that are traded on the stock market. Publicly traded firms may be more responsive to market forces than those that are privately held (Rajan and Zingales, 2003). If privately held firms account for a significant fraction of economic activity, then our results may have limited applicability.

Furthermore, changes in risk sharing are not significant. It is hard to argue that capital is efficiently allocated within countries when the invisible hand appears insensitive to risk.

Indiscriminate hand adherents will fairly point out that we have not addressed the question of whether liberalizations impose long-run real costs in addition to the short-run benefits documented here. The data in this paper pre-date the developing country capital market crises of the mid- to late- 1990s. While it is not clear that stock market liberalizations per se were the proximate cause of these crises, which occurred almost ten years later, the available data do not permit us to address the issue directly. ${ }^{10}$

There is also a great deal of variation in changes in investment that remains to be explained. Previous work suggests some fruitful directions. Firms in industries that are more dependent on external finance may show the largest post-liberalization increases in investment (Rajan and Zingales, 1998). Other explanations could be related to the political economy of

\footnotetext{
${ }^{10}$ See Martin and Reye (2003) for a theoretical examination of liberalization and crises.
} 
liberalization. Firms that receive preferential government treatment may be better positioned to raise stock market financing than other firms (Johnson and Mitton, 2001; Johnson et al. 2000). In turn, preferential treatment may determine which firms are opened up to foreign investment in the first place (Rajan and Zingales, 2001, 2003).

Neither data nor space permits us to pursue such explanations at this time. Nevertheless, the evidence in this paper does bring us a step closer to understanding whether investment is efficiently reallocated when countries remove barriers to international capital movements. Applied to better data in the future, the firm-level identification strategy developed here may bring us yet nearer. 


\section{References}

Acemoglu, Daron and Fabrizio Zilibotti (1997). "Was Prometheus Unbound by Chance? Risk Diversification and Growth," Journal of Political Economy, 105, pp.709-51.

Aitken, Brian and Ann Harrison (1999). "Do Domestic Firms Benefit From Direct Foreign Investment? Evidence from Venezuela," American Economic Review, 89 (3), 605-18.

Baker, Malcolm, Jeremy C. Stein and Jeffrey Wurgler (2003). "When Does the Market Matter? Stock Prices and the Investment of Equity Dependent Firms." Quarterly Journal of Economics, Forthcoming.

Bekaert, Geert and Campbell R. Harvey (2000). "Foreign Speculators and Emerging Equity Markets" The Journal of Finance, Vol. 55, No. 2. pp. 565-613.

Bekaert, Geert, Harvey, Campbell and Lundblad, Christian (2001). "Does Financial Liberalization Spur Growth?” NBER Working Paper \# 8245.

Bhagwati, Jagdish (1998). “The Capital Myth,” Foreign Affairs, May/June pp. 7-12.

Blanchard, Olivier J., Rhee, C., and Lawrence Summers (1993). "The Stock Market, Profit, and Investment," Quarterly Journal of Economics, Vol. 108, pp. 115-36

Booth, Laurence, Varouj Aivazian, Asli Demirguc-Kunt, and Vojislav Maksimovic (2001). Capital Structures in Developing Countries, The Journal of Finance, Vol. 56, pp. 87-130

Chari, Anusha and Peter Blair Henry (2004). Risk Sharing Asset Prices: Evidence From a Natural Experiment," Journal of Finance, Forthcoming.

Fazzari, Steven M., R. Glenn Hubbard, and Bruce C. Petersen (1988). "Financing Constraints and Corporate Investment" Brookings Papers on Economic Activity, Vol. 1988, No. 1. pp. 141-206.

Fischer, Stanley and Robert C. Merton. (1984). "Macroeconomics and Finance: The Role of the Stock Market," Carnegie-Rochester Conference Series on Public Policy, Vol. 21, 57-108.

Fischer, Stanley (1998). "Capital Account Liberalization and the Role of the IMF," Princeton Essays in International Finance 207, 1-10.

Fischer, Stanley (2003). "Globalization and Its Challenges," American Economic Review Vol. 93, No. 2, 1-30.

Frankel, Jeffrey, 1994, "Introduction" in Jeffrey A. Frankel, ed. The Internationalization of Equity Markets, University of Chicago Press, Chicago and London. 
Frankel, Jeffrey and David Romer (1999). "Does Trade Cause Growth?" American Economic Review 89, No. 3, pp. 379-399.

Gujarati, Damodar N. (1988). Basic Econometrics, McGraw Hill, New York.

Henry, Peter Blair. (2000a). "Stock Market Liberalization, Economic Reform, and Emerging Market Equity Prices," Journal of Finance, Vol. 55, No. 2, pp. 529-64.

Henry, Peter Blair. (2000b). "Do Stock Market Liberalizations Cause Investment Booms?" Journal of Financial Economics, Vol. 58, Nos. 1-2, pp. 301-334.

Henry, Peter Blair (2003). "Capital Account Liberalization, The Cost of Capital, and Economic Growth.” American Economic Review, Vol. 93, No. 2, 91-96.

Hubbard, R. Glenn (1998). "Capital Market Imperfections and Investment” Journal of Economic Literature, 36, pp. 193-225.

Johnson, Simon, John McMillan and Christopher Woodruff (2002). "Property Rights and Finance," American Economic Review, 92, 5, pp. 1335-1356.

Johnson, Simon and Todd Mitton (2001). "Cronyism and Capital Controls: Evidence From Malaysia," Journal of Financial Economics, 67, 2, pp. 351-382.

Johnson, Simon, Peter Boone, Alasdair Breach and Eric Friedman (2000). "Corporate Governance in the Asian Financial Crisis, 1997-98," Journal of Financial Economics 58,1-2, pp. 141-186.

Kaplan, Steven and Luigi Zingales (1997). "Do Investment-Cash Flow Sensitivities Provide Useful Measures of Financing Constraints?" Quarterly Journal of Economics, 112, pp. $159-216$.

Kaplan, Steven and Luigi Zingales (2000). "Investment-Cash Flow Sensitivities Are Not Valid Measures of Financing Constraints", Quarterly Journal of Economics, 115, pp. 707-712.

Keynes, John Maynard (1936). The General Theory of Employment, Interest, and Money. London: Macmillan.

Lang, Larry H. P. and Rene M. Stulz (1994). "Tobin's q, Corporate Diversification, and Firm Performance" The Journal of Political Economy, Vol. 102, No. 6. pp. 1248-1280.

Levine, Ross and Sarah Zervos (1998). "Stock Markets, Banks, and Economic Growth," American Economic Review, 88, pp. 537-558.

Levine, Ross (1997). "Financial Development and Growth: Views and Agenda" Journal of Economic Literature, 35, 2, pp. 688-726. 
Levine, Ross (2001). "International Financial Liberalization and Economic Growth" Review of International Economics, 9, 4, pp. 688-702.

Lewis, Karen K. (1999). “Trying to Explain Home Bias in Equities and Consumption” Journal of Economic Literature, 571-608.

Lewis, Karen K. (2000). "Why Do Stocks and Consumption Imply Such Different Gains from International Risk Sharing?” Journal of International Economics 52, 1-35.

Martell, Rodolfo and René M. Stulz (2003). "Equity Market Liberalizations as Country IPOs," American Economic Review Vol. 93, No.2, 97-101

Martin, Philippe and Héléne Rey (2003). "Financial Globalization and Emerging Markets: With or Without Crash?” NBER Working Paper \# 9288.

Obstfeld, Maurice (1994). "Risk-Taking, Global Diversification and Growth," American Economic Review, Vol. 84, No. 5, pp. 1310-1329.

Obstfeld, Maurice (1998). “The Global Capital Market: Benefactor or Menace?” Journal of Economic Perspectives, Vol. 12, No.4, pp. 9-30.

Obstfeld, Maurice and Ken Rogoff (1996). Foundations of International Macroeconomics. MIT Press, Cambridge, MA.

Rajan, Raghuram and Luigi Zingales (1998). "Financial Development and Growth," American Economic Review, 88, pp. 559-86.

Rajan, Raghuram and Luigi Zingales (2001). "The Great Reversals: The Politics of Financial Development in the $20^{\text {th }}$ Century," Journal of Financial Economics, 69, 1, pp. 3-34.

Rajan, Raghuram and Luigi Zingales (2003). Saving Capitalism From the Capitalists, Random House, New York.

Rodrik, Dani (1998). Who needs capital account convertibility? Princeton Essays in International Finance 207, 55-65.

Rogoff, Kenneth (1999). "International Institutions for Reducing Global Financial Instability," Journal of Economic Perspectives, Vol. 13, No. 4, pp.21-42.

Shiller, Robert (1981). "Do Stock Prices Move Too Much to be Justified by Subsequent Changes in Dividends?", American Economic Review, 71(3): 421-436.

Shiller, Robert (2000). Irrational Exuberance, Princeton University Press, Princeton.

Stein, Jeremy C. (2003). "Agency, Information and Corporate Investment" in the Handbook of the Economics of Finance, Constantinides, Harris and Stulz eds., Forthcoming. 
Stiglitz, Joseph (1999). "Reforming the Global Economic Architecture: Lessons From Recent Crises," Journal of Finance 54, 1508-1521.

Stiglitz, Joseph (2002). Globalization and Its Discontents. W.W. Norton, New York.

Stulz, René M. (2003). “Should We Fear Capital Flows?” in Leonardo Auernheimer, ed. InternationalFinancial Markets: The Challenge of Globalization. University of Chicago Press, Forthcoming.

Stulz, René M. (1999). "International Portfolio Flows and Security Markets" in Martin Feldstein, ed. International Capital Flows. Chicago: University of Chicago Press.

Summers, Lawrence H. (2000). "International Financial Crises: Causes, Prevention, and Cures," American Economic Review, Vol. 90, No.2, pp. 1-16.

Summers, Lawrence (1985). "On Economics and Finance," Journal of Finance, Vol. 40, No.3, pp. 633-35.

Wurgler, Jeffrey (2000). "Financial Markets and the Allocation of Capital," Journal of Financial Economics, Vol. 58, pp. 187-214. 
Figure 1. The Growth Rate of Firms' Capital Stocks Increase Following Liberalizations.

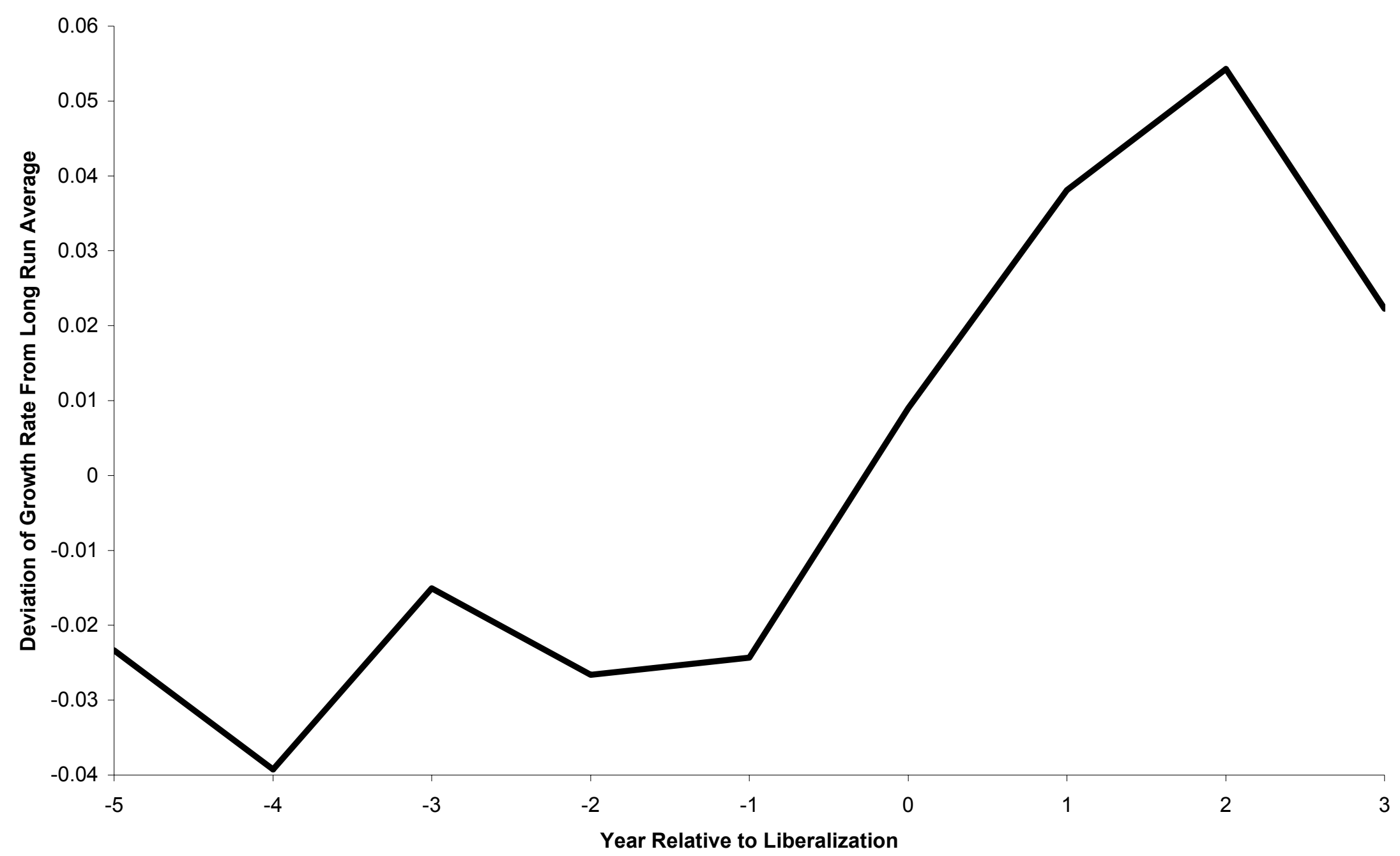

Figure 1. Capital stock growth is the growth rate of firm $i$ 's capital stock in year $t$ minus the average growth rate of firm $i$ 's capital in the entire period preceding the liberalization $(t=[-1,-5])$. The $y$-axis measures the average growth rate of the capital stock across the firms in our sample. The $x$-axis measures time in terms of years relative to liberalization: $t=0$ is the liberalization year; $t=[-1,-5]$ is the pre-liberalization period and $t=[+1,+3]$ is the post-liberalization period. 
Figure 2. The Rate of Return to Capital Rises With Liberalization.

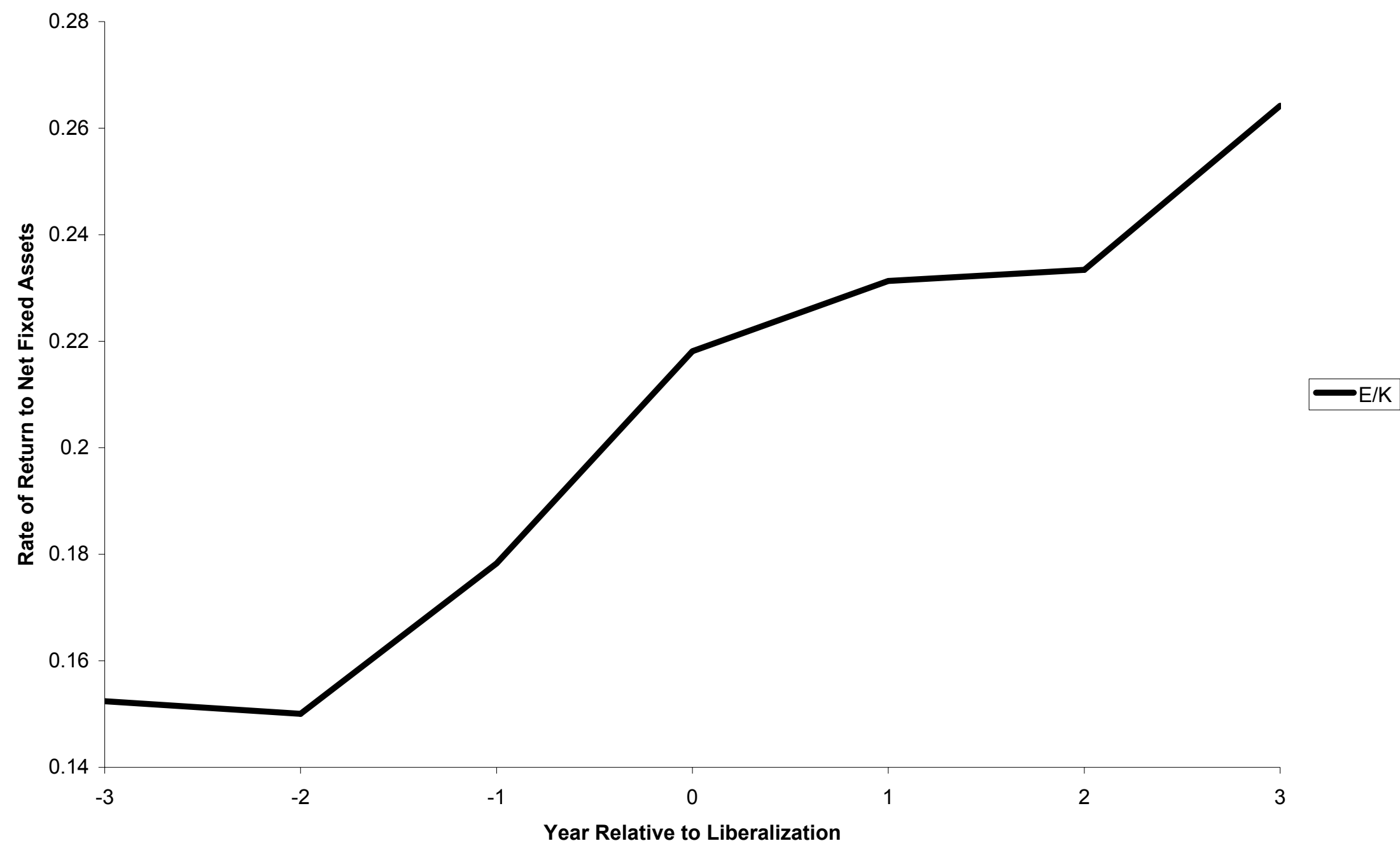

Figure 2. The $\mathrm{y}$-axis represents $\mathrm{E} / \mathrm{K}$ which is the average rate of return to net fixed assets or the aggregate rate of return to capital. For each firm, we compute the flow return to the stock of capital as the ratio of earnings before interest and taxes to the value of net fixed assets. E/K represents the average of this ratio across the 369 firms in our sample. The $x$-axis measures time in terms of years relative to liberalization: $t=0$ is the liberalization year; $t=[-1,-3]$ is the preliberalization period and $\mathrm{t}=[+1,+3]$ is the post-liberalization period. 
Figure 3. Sales and Earnings Growth Increase With Liberalization.

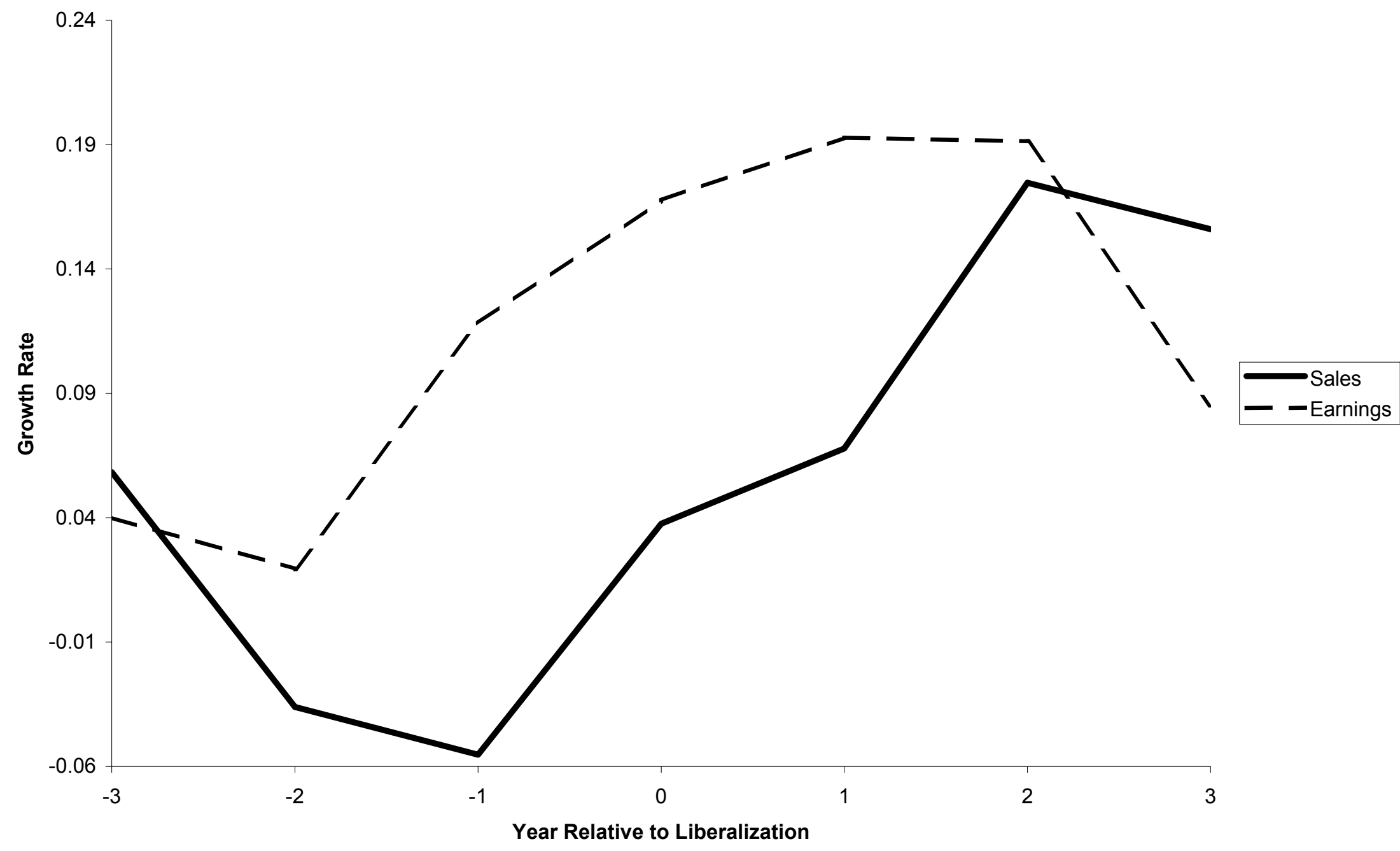

Figure 3. Sales and earnings growth are the first difference of the log of sales and earnings for any given firm. The y-axis measures the average growth rate of sales and earnings across the firms in our sample. The $\mathrm{x}$-axis measures time in terms of years relative to liberalization: $\mathrm{t}=0$ is the liberalization year; $\mathrm{t}=[-1,-3]$ is the pre-liberalization period and $\mathrm{t}=[+1,+3]$ is the post-liberalization period. 
Table 1. The Firms in Our Sample Constitute a Substantial Fraction of Economic Activity in Their Country.

\begin{tabular}{|c|c|c|c|c|}
\hline Country & $\begin{array}{l}\text { Market Capitalization } \\
\text { of Firms as a Fraction of } \\
\text { Total Market Capitalization }\end{array}$ & Number of Firms & Liberalization Year & $\begin{array}{l}\text { Percentage Change } \\
\text { in Tobin's } Q \text { During } \\
\text { Liberalization Year }\end{array}$ \\
\hline India & 0.25 & 99 & 1992 & 81.5 \\
\hline Jordan & 0.14 & 35 & 1987 & 9.6 \\
\hline Korea & 0.38 & 89 & 1987 & 57.7 \\
\hline Malaysia & 0.45 & 85 & 1987 & -28.5 \\
\hline Thailand & 0.66 & 61 & 1988 & 95.9 \\
\hline Full Sample & 0.40 & 369 & NA & 46.1 \\
\hline
\end{tabular}


Table 2. The Firm-Level Investment Boom is Economically and Statistically Significant.

\begin{tabular}{|c|c|c|c|c|}
\hline $\begin{array}{l}\text { Right-Hand-Side } \\
\text { Variables }\end{array}$ & $(1)$ & $(2)$ & (3) & (4) \\
\hline LIBERALIZATION[0] & $\begin{array}{r}0.018 \\
(0.017)\end{array}$ & $\begin{array}{c}0.023 \\
(0.018)\end{array}$ & $\begin{array}{r}0.041 * \\
(0.021)\end{array}$ & $\begin{array}{l}0.047 * * \\
(0.022)\end{array}$ \\
\hline LIBERALIZATION[+1] & $\begin{array}{l}0.055 * * * \\
(0.020)\end{array}$ & $\begin{array}{l}0.062 * * * \\
(0.021)\end{array}$ & $\begin{array}{l}0.044 * \\
(0.024)\end{array}$ & $\begin{array}{l}0.047^{*} \\
(0.025)\end{array}$ \\
\hline LIBERALIZATION[+2] & $\begin{array}{l}0.069 * * * \\
(0.020)\end{array}$ & $\begin{array}{l}0.077 * * * \\
(0.021)\end{array}$ & $\begin{array}{l}0.077 * * * \\
(0.025)\end{array}$ & $\begin{array}{l}0.082 * * * \\
(0.026)\end{array}$ \\
\hline LIBERALIZATION[+3] & $\begin{array}{l}0.039 * * \\
(0.020)\end{array}$ & $\begin{array}{l}0.047 * * \\
(0.021)\end{array}$ & $\begin{array}{l}0.063 * * \\
(0.032)\end{array}$ & $\begin{array}{l}0.069 * * \\
(0.033)\end{array}$ \\
\hline $\begin{array}{l}\text { Sum of } \\
\text { LIBERALIZATION }[0,+3]\end{array}$ & $\begin{array}{l}0.041 * * * \\
(0.013)\end{array}$ & $\begin{array}{l}0.048 * * * \\
(0.013)\end{array}$ & $\begin{array}{c}0.049 * * * \\
(0.017)\end{array}$ & $\begin{array}{l}0.054 * * * \\
(0.018)\end{array}$ \\
\hline
\end{tabular}

Notes: Table 2 presents results for alternative specifications of the benchmark regression, which is given by the following equation: $\Delta(\ln K)_{i j t}=\alpha+L i b[0]+L i b[+1]+L i b[+2]+L i b[+3]+F_{i r m}+\varepsilon_{i j t}$. Rows 1, 2, 3, and 4, present the coefficient estimates for the liberalization year and years 1, 2 and 3 post-liberalization, respectively. Row 5 presents the cumulative coefficient estimate for the four years taken together. The left-hand-side variable is the first difference of the $\log$ of the capital stock (investment). Column (1) presents the coefficient estimates for the regression specification that controls for firm-fixed effects. Column (2) presents the coefficient estimates for the regression specification that controls for country-fixed effects. Column (3) controls for world business cycle effects: the contemporaneous growth rate of OECD industrial production, the three-month real US Treasury bill rate, and the 10year real US government bond rate Column (4) incorporates controls for both firm-fixed effects and world business cycle effects. All specifications control for clustering in the error structure. The symbols $\left({ }^{* * *}\right),\left({ }^{* *}\right)$ and $(*)$ represent significance at the $1 \%, 5 \%$ and $10 \%$ levels, respectively. Standard errors are in parentheses. 
Table 3. Investment Responds More Strongly to Current Sales Growth During Liberalization Years.

\begin{tabular}{|c|c|c|c|c|c|c|}
\hline Right-Hand-Side Variables & $(1)$ & $(2)$ & (3) & $(4)$ & $(5)$ & $(6)$ \\
\hline SALESGROWTH & $\begin{array}{l}0.3072 * * * \\
(0.0186)\end{array}$ & & $\begin{array}{l}0.1593 * * * \\
(0.015)\end{array}$ & & $\begin{array}{l}0.1084 * * * \\
(0.016)\end{array}$ & $\begin{array}{l}01239 * * * \\
(0.015)\end{array}$ \\
\hline SALESGROWTH*LIBERALIZATION & $\begin{array}{l}0.0555^{*} \\
(0.0302)\end{array}$ & & $\begin{array}{l}0.1788 * * * \\
(0.027)\end{array}$ & & $\begin{array}{l}0.2085 * * * \\
(0.028)\end{array}$ & $\begin{array}{l}01899 * * * \\
(0.0288)\end{array}$ \\
\hline FUTURESALESI & & $\begin{array}{l}0.1004 * * * \\
(0.0177)\end{array}$ & $\begin{array}{l}0.1158 * * * \\
(0.0154)\end{array}$ & & & $\begin{array}{l}01499 * * * \\
(0.016)\end{array}$ \\
\hline FUTURESALES1 *LIBERALIZATION & & $\begin{array}{l}0.0316 \\
(0.0301)\end{array}$ & $\begin{array}{l}-0.021 \\
(0.028)\end{array}$ & & & $\begin{array}{l}-00559 \\
(0.0303)\end{array}$ \\
\hline FUTURESALES2 & & & & $\begin{array}{l}0.0491 * * \\
(0.021)\end{array}$ & $\begin{array}{l}0.0579 * * * \\
(0.0164)\end{array}$ & $\begin{array}{l}0.070 * * * \\
(0.016)\end{array}$ \\
\hline FUTURESALES2*LIBERALIZATION & & & & $\begin{array}{l}0.0141 \\
(0.034)\end{array}$ & $\begin{array}{l}-0.0386 \\
(0.035)\end{array}$ & $\begin{array}{l}-0.0547 \\
(0.0311)\end{array}$ \\
\hline Constant & $\begin{array}{l}0.0648 * * * \\
(0.006)\end{array}$ & $\begin{array}{l}0.1064 * * * \\
(0.005)\end{array}$ & $\begin{array}{l}0.0919 * * * \\
(0.005)\end{array}$ & $\begin{array}{l}0.1117 * * * \\
(.006)\end{array}$ & $\begin{array}{l}0.1035^{* * *} \\
(0.005)\end{array}$ & $\begin{array}{l}0.0862 * * * \\
(0.005)\end{array}$ \\
\hline R-squared & 0.13 & 0.03 & 0.08 & 0.02 & 0.05 & 0.08 \\
\hline
\end{tabular}


Table 4. The Firms in Our Sample Have Access to External Finance.

\begin{tabular}{|c|c|c|c|}
\hline Variable & $\begin{array}{c}\text { Pre-Liberalization } \\
\text { Average } \\
\end{array}$ & $\begin{array}{c}\text { Post-Liberalization } \\
\text { Average }\end{array}$ & $\begin{array}{c}\text { Post-Liberalization } \\
\text { Average Differs From } \\
\text { Pre? }\end{array}$ \\
\hline $\begin{array}{l}\text { Change in } \\
\text { Dividends/NFA }\end{array}$ & 0.0336 & 0.0525 & Yes*** \\
\hline $\begin{array}{l}\text { Change in Long-term } \\
\text { liabilities/change in NFA }\end{array}$ & 0.521 & 2.222 & No \\
\hline $\begin{array}{l}\text { Change in External } \\
\text { Finance1/Change in NFA }\end{array}$ & 0.237 & 1.357 & No \\
\hline $\begin{array}{l}\text { Change in External } \\
\text { Finance } 2 / \text { Change in NFA }\end{array}$ & 1.192 & 1.285 & No \\
\hline $\begin{array}{l}\text { Change in Retained } \\
\text { Earnings/Change in NFA }\end{array}$ & 0.516 & 1.534 & No \\
\hline $\begin{array}{l}\text { Change in Internal } \\
\text { sources/NFA }\end{array}$ & 0.015 & 0.080 & Yes* \\
\hline $\begin{array}{l}\text { Change in equity/change } \\
\text { in NFA }\end{array}$ & 0.363 & 1.026 & No \\
\hline
\end{tabular}

Change in dividends/NFA is the first difference of the log of the ratio of dividends divided by net fixed assets for each firm. External Finance1 for each firm is the sum of long-term liabilities and net worth less retained earnings. Change in external financel is the first difference of the log of external finance 1 for each firm. Change in NFA is the first difference of the log of net fixed assets for each firm. External Finance 2 for each firm is the sum of total liabilities and net worth less retained earnings. Change in external finance 2 is the first difference of the log of external finance 2 for each firm. Change in retained earnings is the first difference of the log of retained earnings or total reserves for each firm. Internal sources is earnings after taxes less dividends paid for each firm. Change in internal sources/NFA is the first difference of the log of internal sources to net fixed assets for each firm. Equity is paid in capital or net worth less retained earnings. All changes are calculated on an annual basis for each firm. Pre-lib average is the average for any given variable across firms and countries for the period $t=-3$ to $t=-1$. Post-liberalization average is the average for any given variable across firms and countries for the period $t=0$ to $t=+3$. 
Table 5. Changes in Firms' Fundamentals Significantly Predict Their Post-Liberalization Changes in Investment.

\begin{tabular}{|c|c|c|c|c|c|c|c|}
\hline $\begin{array}{l}\text { Right-Hand-Side } \\
\text { Variables }\end{array}$ & $(1)$ & $(2)$ & $(3)$ & $(4)$ & $(5)$ & $(6)$ & $(7)$ \\
\hline CONSTANT & $\begin{array}{c}0.041^{* * *} \\
(0.010)\end{array}$ & $\begin{array}{l}0.019 * * \\
(0.009)\end{array}$ & $\begin{array}{l}0.028^{* * *} \\
(0.011)\end{array}$ & $\begin{array}{l}-0.0003 \\
(0.009)\end{array}$ & $\begin{array}{l}-0.011 \\
(0.012)\end{array}$ & $\begin{array}{l}0.0004 \\
(0.013)\end{array}$ & $\begin{array}{l}-0.013 \\
(.011)\end{array}$ \\
\hline CASHFLOWDEVIATION & & $\begin{array}{l}0.229 * * * \\
(0.047)\end{array}$ & & $\begin{array}{l}0.316^{* * *} \\
(0.047)\end{array}$ & $\begin{array}{l}0.213^{* * *} \\
(0.048)\end{array}$ & & $\begin{array}{l}0.268 * * * \\
(0.048)\end{array}$ \\
\hline FUTUREGROWTH & & $\begin{array}{l}0.315^{* * *} \\
(0.029)\end{array}$ & & $\begin{array}{l}0.287^{* * *} \\
(0.032)\end{array}$ & $\begin{array}{l}0.344 * * * \\
(0.032)\end{array}$ & & $\begin{array}{l}0.339 * * * \\
(0.033)\end{array}$ \\
\hline DIFCOV & & & $\begin{array}{l}0.037 \\
(0.195)\end{array}$ & $\begin{array}{l}-0.027 \\
(0.177)\end{array}$ & & & $\begin{array}{l}-0.069 \\
(0.184)\end{array}$ \\
\hline LIBERALIZATIONRETURN & & & & & $\begin{array}{l}0.0298 * * \\
(0.015)\end{array}$ & $\begin{array}{l}0.057^{* * *} \\
(0.016)\end{array}$ & $\begin{array}{l}0.042 * * * \\
(0.014)\end{array}$ \\
\hline Adjusted R-Squared & 0.01 & 0.088 & 0.00 & 0.09 & 0.10 & 0.01 & 0.12 \\
\hline Number of Observations. & 1293 & 1292 & 1080 & 1079 & 1184 & 1185 & 1054 \\
\hline $\begin{array}{l}\text { Notes: Table } 5 \text { presents results for a } \\
I N V E S T M E N T D E V I A T I O N_{i j t}=\alpha+ \\
\text { defined as the growth rate of the var } \\
\text { side variable is INVESTMENTDEV } \\
\text { three-year period preceding the libe } \\
\text { the average growth rate of firm } i \text { 's s } \\
\text { years }+1 \text { to }+3 \text { minus the average gr } \\
i \text { 's returns with the local market mir } \\
\text { price during the liberalization year. } \\
\text { clustering in the error structure. Th } \\
\text { parentheses. }\end{array}$ & $\begin{array}{l}\text { alternative speci } \\
+C N T R Y_{j}+\beta_{1} C \\
\text { riable in year } t \\
\text { IATION }_{i j t} \text { is th } \\
\text { ralization ( } \mathrm{t}=[-3 \\
\text { ales in the three } \\
\text { rowth rate of fir } \\
\text { nus its historica } \\
\text { CNTRY } Y_{j} \text { repre } \\
\text { ee symbols }\left(^{* * *}\right.\end{array}$ & $\begin{array}{l}\text { ns of the benc } \\
\text { OWDEVIAT } \\
\text { he average gr } \\
\text { th rate of firm } \\
\text { CASHFLOW } \\
\text { eriod precedi } \\
\text { les in the thre } \\
\text { iance with the } \\
\text { set of countr } \\
\text { and }\left(^{*}\right) \text { repres }\end{array}$ & $\begin{array}{l}\text { irk regressior } \\
\text { ijt }+\beta_{2} F U T \\
\text { rate of the } \\
\text { capital stock } \\
\text { IIATION }_{i j t} \text { i } \\
\text { he liberalizat } \\
\text { ear period pr } \\
\text { rld market } L \\
\text { ecific dumm } \\
\text { significance }\end{array}$ & $\begin{array}{l}\text { ich is given by } \\
\text { GROWTH } H_{i j t}+ \\
\text { ble in the thre } \\
\text { ear } t \text { minus the } \\
\text { growth rate o } \\
\text { FUTUREGR } \\
\text { ing the liberal } \\
A L I Z A T I O N R \\
\text { at control for } \\
\text { e } 1 \%, 5 \% \text { and }\end{array}$ & $\begin{array}{l}\text { e following ec } \\
D I F C O V_{i j}+\varepsilon_{i j} \\
\text { ear period prio } \\
\text { rage growth } \mathrm{r} \\
\mathrm{m} i \text { 's sales gro } \\
T H_{i j t} \text { is the g1 } \\
\text { ion. DIFCOI } \\
U R N_{i j} \text { is the p } \\
\text { intry fixed eff } \\
\text { o levels, respe }\end{array}$ & $\begin{array}{l}\text { ion: } \\
t \in[0,+3] . \text { A } \\
\text { the liberaliza } \\
\text { of firm } i \text { 's cal } \\
\text { in the libera } \\
\text { th rate of firm } \\
\text { the historica } \\
\text { ntage change } \\
\text { All specific } \\
\text { ely. Standar }\end{array}$ & $\begin{array}{l}\text { eviations are } \\
\text { The left-hand- } \\
\text { stock in the } \\
\text { ion year minus } \\
\text { sales growth in } \\
\text { ariance of firm } \\
\text { irm } i \text { 's real stock } \\
\text { ns control for } \\
\text { cors are in }\end{array}$ \\
\hline
\end{tabular}


Table 6. Changes in Firms' Fundamentals Significantly Predict Their Post-Liberalization Changes in Investment.

\begin{tabular}{|c|c|c|c|c|c|c|c|}
\hline $\begin{array}{l}\text { Right-Hand-Side } \\
\text { Variables }\end{array}$ & $(1)$ & $(2)$ & (3) & $(4)$ & $(5)$ & $(6)$ & $(7)$ \\
\hline CONSTANT & $\begin{array}{l}0.038^{* * *} \\
(0.009)\end{array}$ & $\begin{array}{l}0.0138 \\
(0.008)\end{array}$ & $\begin{array}{l}0.021^{* *} \\
(0.010)\end{array}$ & $\begin{array}{l}-0.0003 \\
(0.009)\end{array}$ & $\begin{array}{l}-0.009 \\
(0.012)\end{array}$ & $\begin{array}{l}0.004 \\
(0.012)\end{array}$ & $\begin{array}{l}-0.014 \\
(0.012)\end{array}$ \\
\hline CASHFLOWDEVIATION & & $\begin{array}{l}0.281 * * * \\
(0.046)\end{array}$ & & $\begin{array}{l}0.316^{* * *} \\
(0.047)\end{array}$ & $\begin{array}{l}0.266 * * * \\
(0.047)\end{array}$ & & $\begin{array}{l}0.312 * * * \\
(0.047)\end{array}$ \\
\hline FUTUREGROWTH & & $\begin{array}{l}0.329 * * * \\
(0.027)\end{array}$ & & $\begin{array}{l}0.289 * * * \\
(0.032)\end{array}$ & $\begin{array}{l}0.344 * * * \\
(0.032)\end{array}$ & & $\begin{array}{l}0.329 * * * \\
(0.034)\end{array}$ \\
\hline DIFCOV & & & $\begin{array}{l}-0.016 \\
(0.186)\end{array}$ & $\begin{array}{l}-0.0273 \\
(0.177)\end{array}$ & & & $\begin{array}{l}-0.044 \\
(0.177)\end{array}$ \\
\hline LIBERALIZATIONRETURN & & & & & $\begin{array}{l}0.021 \\
(0.014)\end{array}$ & $\begin{array}{l}0.046^{* * *} \\
(0.015)\end{array}$ & $\begin{array}{l}0.028 * * \\
(0.013)\end{array}$ \\
\hline Adjusted R-Squared & 0.00 & 0.099 & 0.002 & 0.095 & 0.10 & 0.01 & 0.11 \\
\hline Number of Observations. & 1293 & 1292 & 1080 & 1079 & 1184 & 1185 & 1054 \\
\hline $\begin{array}{l}\text { Notes: Table } 6 \text { presents results for } \\
I N V E S T M E N T D E V I A T I O N_{i j t}=\alpha \\
\text { defined as the growth rate of the va } \\
\text { variable is INVESTMENTDEVIAT } \\
\text { year period preceding the liberaliza } \\
\text { average growth rate of firm } i \text { 's sale } \\
\text { years }+1 \text { to }+3 \text { minus the average } \mathrm{g} \\
i \text { 's returns with the local market mi } \\
i \text { 's real stock price during the liber } \\
\text { control for clustering in the error st } \\
\text { are in parentheses. }\end{array}$ & $\begin{array}{l}\text { alternative spec } \\
+C N T R Y_{j}+\beta_{1} C \\
\text { riable in year } t \\
I O N_{i j t} \text { is the grc } \\
\text { tion (t=[-3,-1]) } \\
\text { in the three-ye } \\
\text { rowth rate of fir } \\
\text { nus its historica } \\
\text { lization year. } \\
\text { ructure. The sy }\end{array}$ & $\begin{array}{l}\text { ns of the bencl } \\
L O W D E V I A T I \\
\text { the average grc } \\
\text { te of firm } i \text { 's ca } \\
\text { HFLOWDEVI } \\
\text { od preceding tl } \\
\text { ales in the thre } \\
\text { iance with the } \\
j \text { represents a } \\
(* * *),(* *) \text { anc }\end{array}$ & $\begin{array}{l}\text { irk regression, } \\
i j t+\beta_{2} F U T U \\
\mathrm{n} \text { rate of the vi } \\
\text { al stock in yea } \\
O N_{i j t} \text { is the gr } \\
\text { iberalization. } \\
\text { ear period pre } \\
\text { rld market } L I t \\
\text { of country spe } \\
\text { represent sig }\end{array}$ & $\begin{array}{l}\text { ich is given b, } \\
\text { GROWTH }{ }_{i j t}+ \\
\text { ble in the enti } \\
\text { ninus the aver } \\
\text { h rate of firm } \\
\text { ITUREGROW } \\
\text { ng the liberali } \\
\text { ALIZATIONR } \\
\text { c dummies th } \\
\text { cance at the 1 }\end{array}$ & $\begin{array}{l}\text { e following ec } \\
D I F C O V_{i j}+\varepsilon_{i j} \\
\text { re-liberalizati } \\
\text { growth rate o } \\
\text { sales growth it } \\
\text { is the grow } \\
\text { ion. DIFCOI } \\
U R N_{i j} \text { is the ut } \\
\text { ontrol for cou } \\
5 \% \text { and } 10 \% 1\end{array}$ & $\begin{array}{l}\text { ion: } \\
\in[0,+3] . \mathrm{Al} \\
\text { eriod. The le } \\
\mathrm{m} i^{\prime} \text { s capital } \\
\text { liberalizatic } \\
\text { te of firm } i \text { 's } \\
\text { the historica } \\
\text { ected percen } \\
\text { fixed effects } \\
\text { s, respective }\end{array}$ & $\begin{array}{l}\text { iations are } \\
\text { and-side } \\
\times \text { in the three- } \\
\text { ar minus the } \\
\text { growth in } \\
\text { ariance of firm } \\
\text { change in firm } \\
1 \text { specifications } \\
\text { tandard errors }\end{array}$ \\
\hline
\end{tabular}

